\title{
A Model of Introducing E-learning System at Vocational College for Business Secretaries
}

\author{
Marko Kastelic \\ SŠER, Ljubljana \\ Ljubljana, Slovenija
}

\author{
Tea Lončarič \\ Leila, Ljubljana \\ Ljubljana, Slovenija
}

\section{Marko.Kastelic@guest.arnes.si}

\section{Tea.Loncaric@guest.arnes.si}

\begin{abstract}
In this paper the background, the context and the main challenges of introducing e-learning at vocational college for business secretaries will be examined. The presented data were gathered from surveys considering all phases of experimental project that took place in the academic year 2005/06 at vocational college Leila in Ljubljana, Slovenia.

This article begins with a brief description of circumstances that influenced the research of implementing new technologies in teaching and learning processes. What follows is a general introduction into the field of e-learning and e-learning environments.

The main part of this article describes the whole process of integrating e-education into the program for business secretaries. The final part of the article summarizes the work so far and gives some suggestions for the future.
\end{abstract}

Keywords: vocational college, adult education, e-learning strategy, e-education, e-learning environment, open source software, SCORM, key elements of success.

\section{Introduction}

After Slovenia became an independent state in 1991 the transition process started. The consequence of deep economic and social changes is the adaptation in all fields including education. There were many formal changes in educational system including emergence of new freestanding vocational and higher educational institutions as well as new educational programs. Improvements in quality of education and the concept promoting lifelong learning are included in the government's guideline for development of Slovenia in the periods: 2001-2006 (Ammerman, 2004) and 2006-2013 as high priority factors for achieving the main goals.

At present (2006) there are 51 vocational colleges in Slovenia. 19 of them are offering educational program for business secretaries. Many students are interested in this program. According

Material published as part of this publication, either on-line or in print, is copyrighted by the Informing Science Institute. Permission to make digital or paper copy of part or all of these works for personal or classroom use is granted without fee provided that the copies are not made or distributed for profit or commercial advantage AND that copies 1) bear this notice in full and 2) give the full citation on the first page. It is permissible to abstract these works so long as credit is given. To copy in all other cases or to republish or to post on a server or to redistribute to lists requires specific permission and payment of a fee. Contact Publisher@InformingScience.org to request redistribution permission. to the preliminary data in the academic year 2006/07 there are $14 \%$ of students attending this program (see Table 1).

The growing competition among these 19 schools claims modernization, updating and upgrading of current ways of teaching and learning. These changes must take into consideration specific demands and characteristics of adult population. At the same time it is an 
opportunity and a challenge to introduce new ways and improve existing educational system. Schools have to provide modern way of learning, quicker on- and off-line communication between students and their teacher as well as among students, and simplify the process of disseminating students work and experience. The way of learning should be such that every student has the ability to adjust to the place, time, and the way of learning according to his/her needs.

\begin{tabular}{|l|l|c|}
\hline \multicolumn{3}{|l|}{ Table 1 Registered students at vocational colleges in the academic year 2006/07 } \\
\hline Program & No. of students & Percentage \\
\hline Commercialist & 3.392 & $20,3 \%$ \\
\hline Business Secretary & 2.327 & $\mathbf{1 3 , 9 \%}$ \\
\hline Accounting & 1.698 & $10,2 \%$ \\
\hline Mechanical engineering & 1.493 & $8,9 \%$ \\
\hline Other 18 programs & 7.806 & $46,7 \%$ \\
\hline
\end{tabular}

This new approach to education makes room for a more flexible time frame which, without stating the fact, clearly makes it possible for learners with different abilities to steer their path of intellectual growth in such a way that they stay within the borders of the flow channel (Steyn 2001).

Therefore within vocational colleges the interest for e-learning has constantly been increasing. Despite the great interest in introducing e-learning these efforts are still in the beginning phase and are too often one-man research projects of individuals who believe that e-learning will soon be accepted as a rule and a minimal standard at numerous colleges.

In the academic year 2004/05 the vocational college Leila started with e-learning as an experimental project with a small group of 17 students. The goal of the research project was to find out whether and how the students accept changes in the ways of learning and communicating. The second goal was to find out whether students have the basic infrastructure for using e-learning systems.

In the academic year 2005/06 the college offered full support in e-learning for one subject for first-year students and partial support for 3 other subjects.

In the following year (2006/07) e-learning support was extended to 6 new subjects. The existent support was supplemented with some new features.

\section{E-learning}

In the academic and business world the term e-learning is used as a new term for distance learning through internet or web based training.

In fact there is a misuse of the word 'e-learning' because most of e-learning systems provide services for both parties of the educational process: students and teachers. The appropriate term would therefore be 'e-education'. E-education can be defined by a simple equation: e-education = e-learning + e-teaching. E-education should be supported by appropriate system.

According to Thomas Dietinger (2003) the basic components of an e-education system are:

- $\quad$ students - people, who are using e-learning system part of e-education system to achieve learning goal,

- teachers - people, who are using e-teaching part of system that monitor, guide, help and assist students when trying to achieve learning goal, 
- e-content - e-content presents learning goal and should describe the way, how that goal can be achieved. E-content should provide students with all important information, and the ways of self-evaluation. Computer based presentation enables to enhance e-content with multimedia and interactive elements,

- technology - obsolete classroom education with the usage of ICT was very poor. In most cases classroom education includes only a PC and a digital projector, and maybe a digital blackboard. In e-education functionality and simplicity of e-learning environment is one of the most critical key factors for success. E-education environment should be accessed using a web browser over the internet or intranet. To fulfill its task e-learning environment should provide different ways of interaction, communication and collaboration among all participants in e-education. Another feature of e-environment is to provide monitoring, help and assistance. Learning Management System (LMS) allows users to access and deliver training content. It also includes tools for tracking and reporting usertraining performance (Martin. IBM systems Journal). There are several other terms for eeducation technology: Learning Management Platform (LMP), WBT-System (Web Based Training System), CMS (Content Management System), etc. The core features of all systems are very similar so only minor differences exist.

\section{The Basic Request for Introducing Pure E-environment System}

Although many analysts predict fast growth for e-education there are only few organizations in Slovenia which offer e-courses. What is the reason for this?

For successful introduction of e-learning system some basic conditions should be fulfilled (Keegan et al. 1993). These conditions are: large base of installed computers in the home and workplace, network security, infrastructure and suitable bandwidth, cheap and reliable access to the internet, and the last very important condition is human acceptance of the cyber space.

In Slovenia the first three conditions are almost completely fulfilled.

The only but also the biggest problem is the fourth condition. E-education participants should accept the cyber space as a part of the real world and should equalize events in the cyber space with those in the real world. In certain fields the consumers have accepted cyber events as 'real'. For example many people are using e-banking or e-government services, listening internet radio, etc.

Another example is e-shopping. The e-commerce providers are very disappointed because most customers use internet just for collecting information, and then they do the 'traditional' shopping.

Very similar to e-shopping is the field of education. In Slovenia the usage of e-education is among the lowest of the $25 \mathrm{EU}$ countries (Bregar \& Zagmajster, 2005). There are several reasons for that:

- lack of confidence in the outcome of e-educational process,

- need for change in students' and teacher's minds,

- long duration and hard process of building e-content,

- lack of experience in e-education,

- modest offer of e-contents and

- relatively small market for e-educational content due to Slovenian language. 


\section{A Case of E-education Deployment at the Vocational College Leila}

The starting point of introducing e-education was the agreement on understanding e-education in the broadest sense. E-education stands for using modern ICT (information communication technology) in teaching and learning to enhance traditional classroom education and achieve better results. Although e-education can be introduced as a standalone educational system, we decided to combine it with traditional education.

At the moment the college uses a hybrid educational system: classroom education plus eeducation. So far, e-education is understood as adding value to classical education. Most of participants are novices in online teaching and learning and the college provides a telephone helpline for resolving access and password problems. In the future there is a possibility to develop and offer standalone e-education courses. In the following sections the ways of introducing eeducation are presented.

\section{1st Step: Defining e-education Strategy}

'The reason why you need an e-learning strategy is to define the goals for your e-learning program and then logically explain how you will prove that the goals have been met.' (De Vries, 2005)

At the very beginning the e-education strategy was defined according to the above mentioned statement. The contents of the strategy were:

- goals we wish to achieve through introduction of an e-learning and e-teaching systems and

- the measures that would show us, whether the goals have been met.

\section{The goals of e-education program}

Before defining goals of the e-learning program the strategic needs of the target audience were investigated. The results of this phase were answers to the following key questions:

a) Which are the characteristics and needs of the students?

Experiences from the previous academic year and some interviews showed that students have positive attitude toward using computers and computer technology, their typical platform is PC with operating system Windows or Linux and most of them have access to internet either from home or from office. For some of the students classroom teaching is unsuitable because of their duties at work or at home (sometimes they are so preoccupied with their work that they have to stay at work till five, six or even seven o'clock in the afternoon, and cannot attend classroom lectures, they cannot contact the teacher or other colleagues, etc.)

b) Which are the characteristics and needs of the teaching staff?

The college wanted to know whether there is a person, who is willing to develop and deploy elearning system. A small team of four teachers was found, with enough computer knowledge and bravery to accept the challenge.

c) What kind of attitude does the management have towards the enhancement of classroom teaching with e-learning forms of education?

The management was only partly aware of the abilities of e-learning program. Therefore a demonstration of a sample e-learning platform was made. It was discussed how the proposed system 
could fit in with the organization's strategic direction. The outcome was the decision to start with an introduction of the proposed e-learning platform at vocational college Leila.

After that preliminary investigation the team defined the goals that needed to be achieved. These goals were:

- Enable students a uniform access to all teaching materials at one place 24 hours a day and 7 days per week.

- Direct students toward other learning resources on the internet.

- Improve and accelerate communication between students and teachers / trainers.

- Improve and accelerate communication among students.

- Stimulate students' team work.

- Enable students to adjust place, speed and way of learning according to their needs and capabilities.

- Provide students with self evaluation mechanism.

- Facilitate teachers monitoring students' progress.

- Simplify and speed up the procedure notifying students.

- Track student's response, their initiative, suggestions and needs.

- Automate monitoring system of student progress.

- Ensure privacy and security.

- Implant netiquette in students' and teachers' minds.

\section{2nd Step: Formulating e-educational Strategy = Designing Fu- ture System}

In this phase the three key elements of the e-learning strategy were defined: technology, content, and administration and support.

\section{Technology: The selection of Learning Content Management System}

During the selection of LCMS the team considered all the results of the investigation phase: established characteristics and needs of students and teachers. At that time most of them did not have broadband access to the internet and first phase of implementation required LMS with only asynchronous technology. The prediction was that in the near future most of our clients would have a broadband access to the internet. Therefore the team was looking for a LMS or LCMS that support both synchronous and asynchronous technologies.

Minimal feature set of an LCMS, that would suit the team's needs should include:

- Authoring tool-enables teachers to create content and assessments.

- Assessment services - enables students to do assessments and view scores.

- Learner tracking tool - enables teacher to monitor the progress of their students.

- Learner record tool - enables recording data about learners and enables students to introduce themselves in virtual school community.

- Course catalogue and registration tool - 
- Asynchronous communication functions - email, discussion forum and announcements.

- Synchronous communication functions - chatting or video conferencing system.

- E-learning environment administration management tool - provides administration of all users, courses and classes.

- Courses administration tool - create, modify, back-up and restore courses and to monitor usage of course.

- Tool for administration - create users and classes, this tool should support at least 3 roles: learners, teachers and administration.

- Supporting e-learning standard SCORM. What is SCORM and why is it so important? The e-content should be independent of e-learning environment. If an organization decides to change the platform all old contents must be available without special changes or upgrading. The Shareable Content Object Reference Model (SCORM) is an XML-based framework used to define and access information about learning objects so they can be easily shared among different learning management systems (LMSs). SCORM is a specification of the Advanced Distributed Learning. It was designed to facilitate moving course content and related information (such as student records) from one platform to another, to make course content into modular objects that can be reused in other courses, and to enable any LMS to search others for usable course content.

The second big dilemma was whether to buy a commercial LMS or use freeware LMS. After functional analysis of the few LMS, CMS and LCMS and according to previous decision about an experimental project, the decision was made to use the open source freeware LMS Dokeos. The main reasons for this choice were:

- previous experience with this e-education platform,

- $\quad$ price - Dokeos is free of charge,

- appropriateness regarding operating system - Dokeos runs on different operating systems (including Linux),

- set of features - Dokeos is capable to meet all functional requirements,

- content delivery according to e-learning standards such as SCORM and IMS,

- feasibility to develop and deploy ones own e-educational components,

- Dokeos is continuously evolving.

\section{Dokeos}

Dokeos is an open source e-learning and course management web application translated in 34 languages. The multilingual support is very useful. It enables adapting user interface regarding the course subject. For example the user interface for the course English Language was in English, the user interface for the course German Language was in German and for other two subjects the user interfaces were in Slovene language. Dokeos is also a company helping launch and enables blended learning programs. More information about Dokeos can be found at http://www.dokeos.com/ .

The basic features of Dokeos platform used at the college Leila are: 


\begin{tabular}{|c|c|}
\hline $\begin{array}{c}\text { Teacher's } \\
\text { tools }\end{array}$ & $\begin{array}{l}\text { Description of course - to describe course main goals, evaluation, way of imple- } \\
\text { mentation, additional readings etc. } \\
\text { Documents - for publishing /delivering learning material, homework, instructions, } \\
\text { samples etc... } \\
\text { Announcements - to add and send announcements to the selected or all users by e- } \\
\text { mail. } \\
\text { Test - to create question pool and make interactive quizzes with different kinds of } \\
\text { questions (true/false, multiple choice, filling the blanks, matching). } \\
\text { Agenda - to add, modify and show course agenda. } \\
\text { Drop Box - to accept students work (essays, seminar work, presentations). } \\
\text { Forums - for written discussion among all students and their teacher, for helping } \\
\text { students in preparation for exams, or for answering to common questions, demon- } \\
\text { strating corrections to common mistakes etc. } \\
\text { Links - to direct students toward other learning resources on the internet. } \\
\text { Tracking tool - to monitor usage and to follow students' progress. } \\
\text { Chat - to chat with students, pleasant way of informal contact with students. }\end{array}$ \\
\hline $\begin{array}{l}\text { Student's } \\
\text { tools }\end{array}$ & $\begin{array}{l}\text { Students were using all available tools, especially documents, tests, announce- } \\
\text { ments, drop box and links. Some students enjoyed chatting. }\end{array}$ \\
\hline $\begin{array}{l}\text { Learning } \\
\text { system } \\
\text { adminis- } \\
\text { trator's } \\
\text { tools }\end{array}$ & $\begin{array}{l}\text { Administration of users - in our case self registration of users was disabled. Learn- } \\
\text { ing environment administrator created all users and assigned them different roles. } \\
\text { For delivering accounts administrator was using integrated e-mail system. } \\
\text { Class management - creating classes, assigning students to classes, assigning } \\
\text { classes to courses. } \\
\text { System management - setting some technical restrictions (for example: maximum } \\
\text { file size for uploading, default parameters for courses etc.). } \\
\text { System announcements - for global announcements regarding the whole e-learning } \\
\text { environment. }\end{array}$ \\
\hline
\end{tabular}

Dokeos's user interface is simple and user-friendly (see Figure 1).

\section{Contents}

In the first phase of the project the team decided to include e-education support for only four subjects: computer science, computer practicum, English and German language. Through eeducation system the students had access to documents, tests, quizzes, agenda, drop box and announcements.

All contents were built by members of the e-teachers team. The existing material was converted into a suitable form and deployed in the e-learning portal. The additional contents (for example questions, quizzes, tests, etc.) are made simultaneously along the course.

For the development of suitable course content the existing licensed software (Windows, MS Office) was chosen, along with certain freeware software tools such as a PDFCreator or eXe eLearning XHTML editor, and authoring tools included in the e-learning environment. 


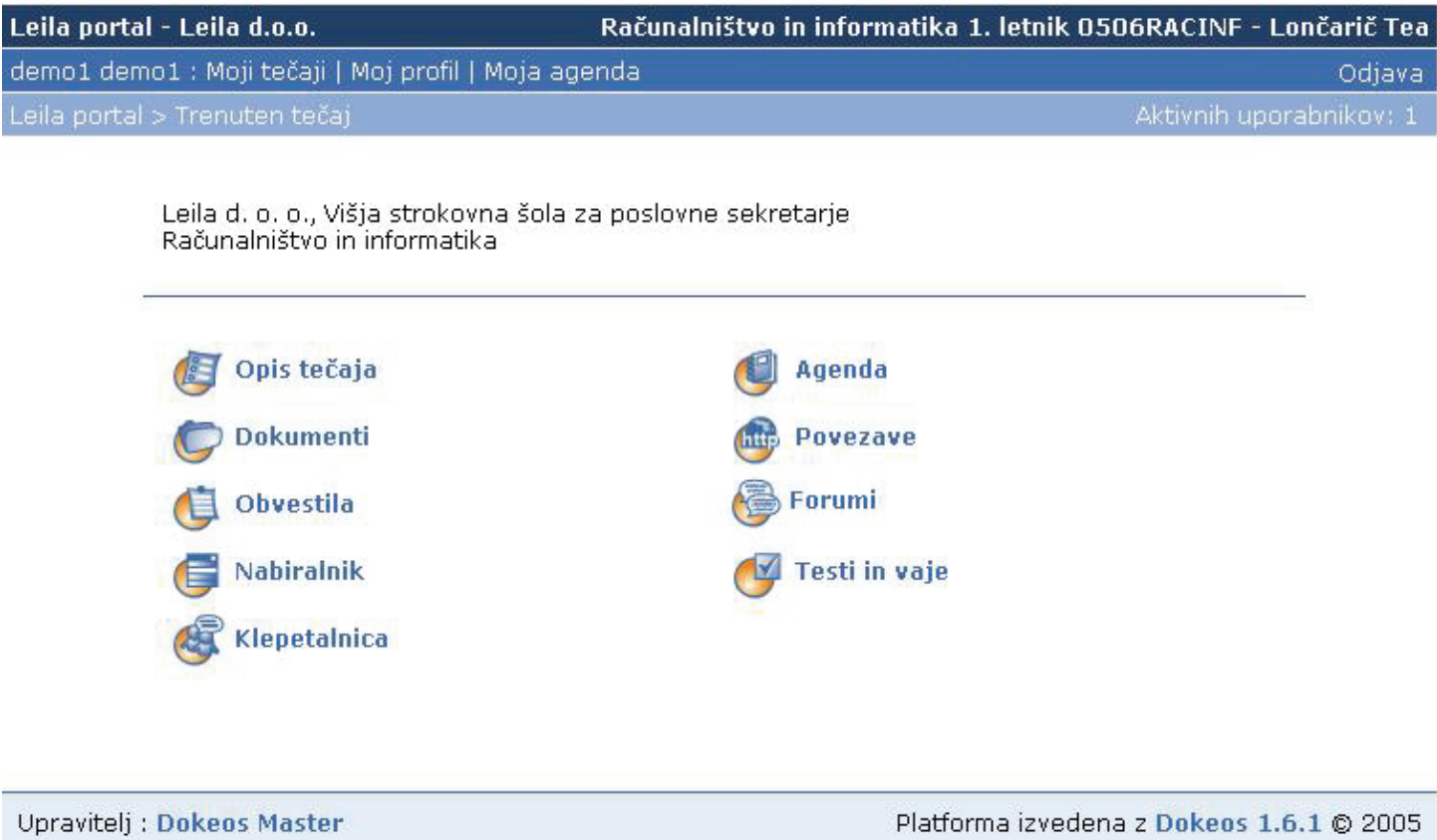

Figure 1 Dokeos user interface for course 'Računalništvo in informatika' (IT)

It was decided to use a triple method of evaluation: assessments included in e-learning portal, the results of exams and above all interviewing students. These methods should drive a feedback loop, so that it would be possible to continuously improve and accommodate e-learning program.

\section{Administration and support}

One of the most important things in introducing new technologies is the confidence of those who use the system. Customers must be certain that if something goes wrong, they would always have a 'rescue exit' - someone, who is going to help them. That 'help pool' duty was assigned to learning system administrator. At the beginning of the academic year the administrator created all user accounts and sent them trough e-learning environment mailing system. The administrator also created courses, set basic common attributes of e-learning environment, regularly created the back-up of the courses and users data. The administrator's responsibility was also monitoring system performance and restoring previous data in case of accidence. The administrator must always be available trough e-mail. One member of the teaching staff has become the learning system administrator.

\section{3rd Step: Implementation and Usage}

\section{Dokeos installation}

Dokeos is a web application written in scripting language PHP. Dokeos uses MySQL database server and works on the web server. According to Dokeos recommendations the team used the Apache web server and installed PHP version 4.3.2 and MySQL server version 4.1. The next step was to unzip the downloaded Dokeos package and move it to the website on the web server. After opening the web browser it was only necessary to follow the installing instructions and finish the installation process. After finishing installation it is wise to protect the configuration file (claro_main.conf.php) and the installation folder and to configure Dokeos mail. The process of the installation was executed without any problems. After approximately three weeks of testing, the first clients started using Dokeos e-learning platform. 


\section{E-learning environment usage}

The users did not have problems or complaints about the e-learning platform. From organizational point of view the main problem was with delivering the user names and passwords. Because of the spam filters on user mail servers some mails were redirected to spam mail folder and users did not notice administrator's message. Many users had problems during the first log-on attempt because they did not consider the fact that passwords are case sensitive. Some users deleted mail (with username and password) by mistake. Many users gave wrong mail addresses the main mistake was in the name-part of the e-mail address. For example they wrote firstname.surname@domain, but the correct mail address was without full stop between the name and surname or they wrote firstname-surname@domain but the correct mail address was firstname_surname@domain etc. Sometimes they wrote a nonexistent domain. There were even cases when students had no e-mail addresses.

Most problems were solved in first two months of usage and since than things have been running smoothly.

\section{E-learning content structure}

E-learning contents for all subjects were structured in a similar way. In Course Description section there was a short description with all relevant information about the course: course objectives, topics that will be covered in the course, course materials, assessment and some other issues specific for that course.

Because of our strategy of blended learning each in-classroom lecture was supported with econtent elements and some e-activities. In Document section all text materials and files with discussion and reflection questions were published.

In Test section for each lecture there was one on-line quiz. On-line quiz consisted of various type questions: true/false, multichoice, multi-select and gap filling (see Figure 2). At the end of the quiz the student received a score for each question, comparison between his/her answers and correct answers, and final score (see Figure 3). The student was allowed to repeat the same quiz several times.

E-activities include discussions in forums about specific topics, doing preparation tests for exam, visiting proposed links to web pages and using Drop Box tool for uploading seminar work. Dokeos registers all rele-

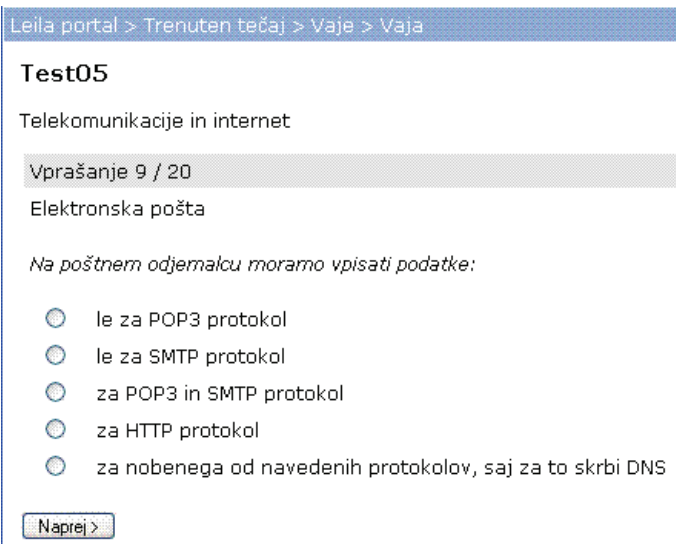

Figure 2 Multi-choice question form vant data about student's activites. One external view over these data is course statistics and the other is review of students' activities. 


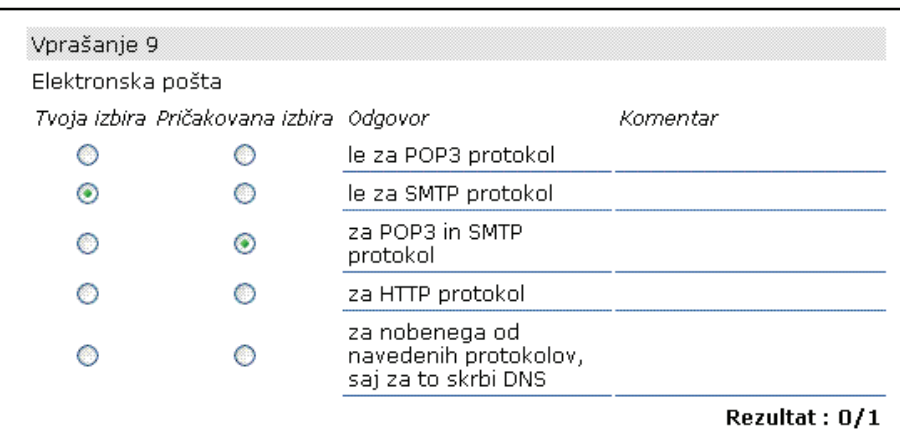

Figure 3 Multi-choice answer form

The teacher used Tracing tool to monitor students' activities and their progress in solving tests. In Figure 4 for example, the teacher can find out that the student $x x x x$ visited the course 8 times in November, 28 times in December and 25 times in January. The student did the Test 2 for three times and each time he/she achieved different score: 15/29, 23/29 and 26/29 points. The same student did the Test 3 only once with score $21 / 24$ points.

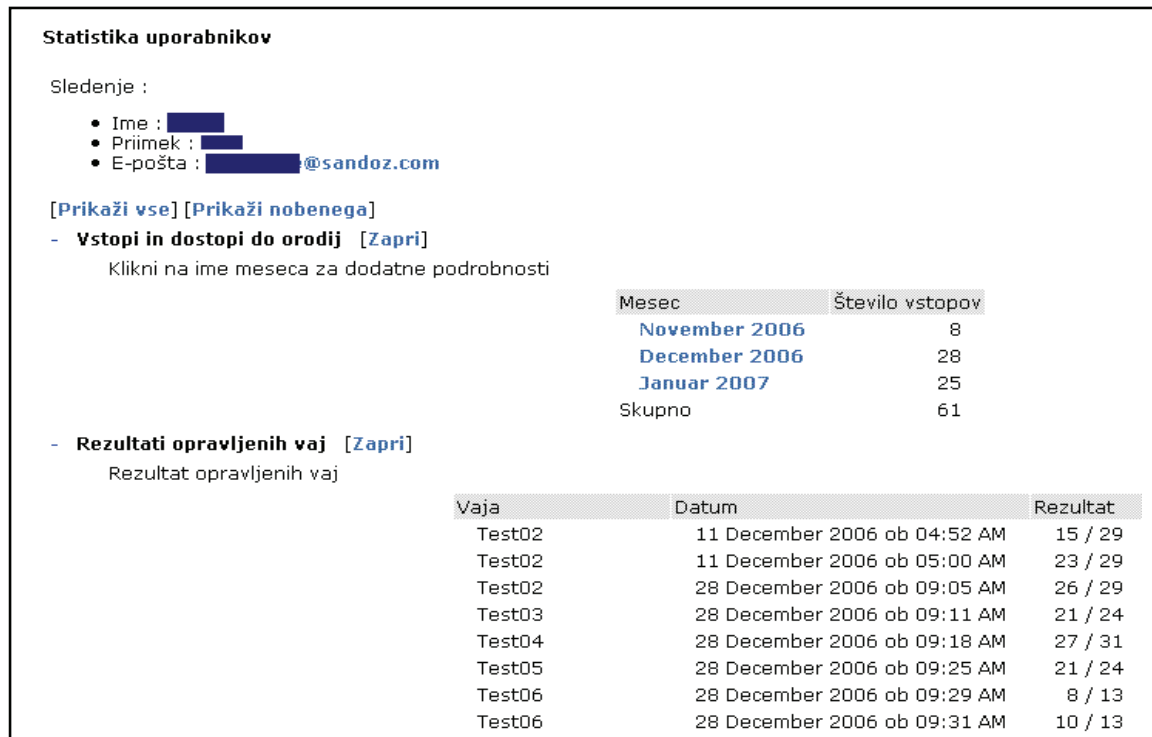

Figure 4 Tracing of student's work on tests

\section{E- assessments}

The final exam for all courses is still carried out in the classroom and consists of written paper and seminar work with oral presentation. In the academic year 2006/2007 it happened for the first time that a student did a complete exam on-line. At that time our candidate was living in Washington and this was the only way to do the exam. This was our first and so far the only experience with assessments trough e-learning platform. The student and the teacher were in contact trough e-mail. During preparation the student was using e-materials published on e-learning portal and had few short chats with the teacher. Through e-mail we arranged time to meet in chat-room for the exam. The course of events during the exam: 
- At the beginning there was a short introduction. The teacher gave some moral support and opened previously prepared test in Tests section. The final test was limited to only 25 minutes for answering without possibility of repeating the quiz or viewing the answers.

- The student worked on test for about 20 minutes. After closing up the test the student and the teacher immediately saw student's score.

- Second part of the exam consisted of few teacher's questions regarding student's seminar work. The seminar work was uploaded in drop box prior to the beginning of the exam. Interview took place in the chat room.

- At the end the student received a mark and after saying goodbye the student went back to work (in Washington it was 4pm) and the teacher went to bed (in Ljubljana it was 10pm).

\section{4th step: Findings}

At the end of the academic year, the team investigated students' opinions about e-learning support, Dokeos platform, and e-learning and administration services. Here are some significant findings gathered from the questionnaire results and basic information about the students:

- average age is 32 years.

- $73 \%$ of students are employed and $27 \%$ are unemployed,

- $68 \%$ of students use internet daily and $32 \%$ use internet only occasionally.

First finding: Most students declared they had been using most of the offered tools, but only $11 \%$ had been using all of the offered tools (see Figure 5).

How many dokeos tools are you using?

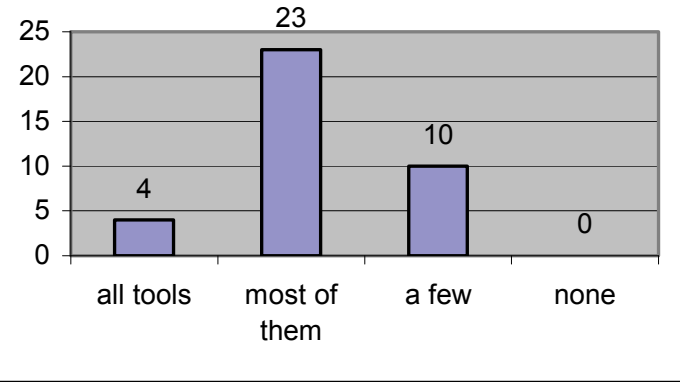

Figure 5 Usage of Dokeos tools

Second finding: Table 2 shows student's opinions about usefulness of Dokeos tools. According to their opinions the best average mark had been given to Announcements and the lowest to Chatting tool.

\begin{tabular}{|c|c|l|l|c|c|c|c|}
\hline \multicolumn{7}{|c|}{ Table 2 Average marks for Dokeos tools } \\
\hline Tool & Announcement & Tests & Links & Documents & $\begin{array}{c}\text { Forum \& } \\
\text { Drop box }\end{array}$ & Agenda & Chatting \\
\hline $\begin{array}{c}\text { Avg. } \\
\text { mark }\end{array}$ & 4,62 & 4,59 & 4,4 & 4,37 & 4,24 & 4,13 & 4 \\
\hline
\end{tabular}

Third finding: Students were rather satisfied with teacher's and administrator support (see Figure 6). 


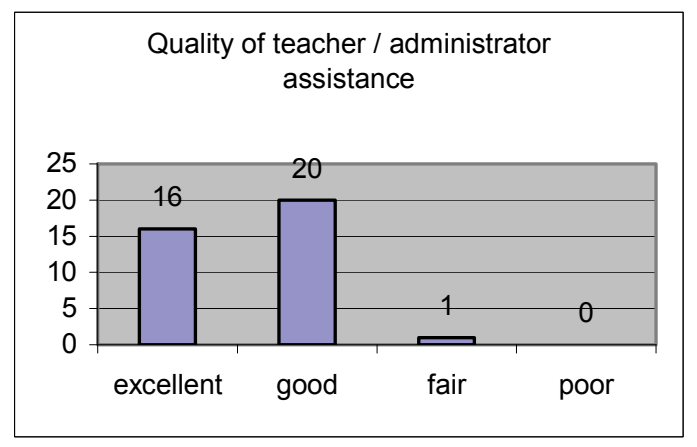

Figure 6 Student's satisfaction with support

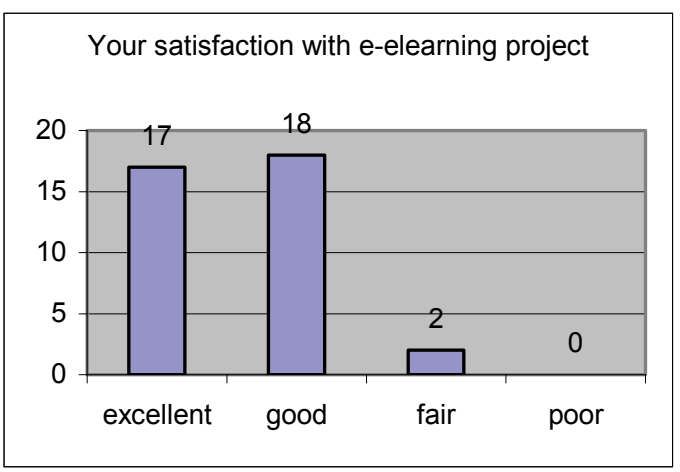

Figure 7 Student's satisfaction with elearning project

Fourth finding: Students were satisfied with new service and most of them wished to continue using e-learning support (see Figure 7).

There was a clear correlation with marks for teacher / administrator assistance. That shows us the importance of the human factor in introducing new technologies.

\section{Conclusions and Recommendations}

This article presented an example of an evolutionary approach toward introducing e-learning to a vocational college. The anticipated difficulties were few and the results are better than expected. The main results of this research are:

- Students accepted the combination of classroom and e-learning environment positively.

- The chosen e-learning environment (Dokeos) proved to be successful.

- The key element of the successful introduction of e-learning is still the human factor: teacher's support and impulse, and learning system administrator's assistance.

The recommendations for the future work include:

- Most of our students have not studied for years, a decade or even more. There is a possibility that there is a gap between their knowledge and the one required for attending the course. Teachers should also give information how and where students can find additional readings or short courses that will help students attend the course. It is recommended to use the Link tool.

- The core participants of the e-education team should pay more attention to educating other teachers and trainers. Classical classroom teachers have to change their behavior and their efforts from teaching towards directing, helping and accustoming students to new ways of learning.

- The majority of the existing lecture notes and readings should be modified into the new form that will include multimedia elements (pictures, sound and movies for demonstration). This will enable not only hybrid learning but also 'pure' e-learning.

- A connection should be made between the learning environment and the administrative part of educational institution. At the moment the missing features of e-learning environment are: the students' formal registration for exams, the formal presentation of results / marks, the formal way for students to complain or to commend. 


\section{References}

About Dokeos. (2006). Retrieved November, 2006, from http://www.dokeos.com

Advanced Distributed Learning. (n.d.). Retrieved November 2006 from http://www.adlnet.gov/

Ammerman, P. (2004). Achieving the Lisbon goal: The contribution of vocational education and training systems. Country Report: Slovenia. Retrieved November, 2006, from http://www.ris.org/index.php?fl=2\&lact $=1 \&$ bid $=1380 \&$ parent $=17 \&$ cat $=75 \& p 1=276 \& p 2=285 \& i d=288$

Bregar, L. \& Zagmajster, M. (2005). E-learning in Slovene higher education. Medien in der Wissenschaft, $35,237-251$.

De Vries, J. (2005). E-learning strategy: A framework for success. Retrieved September, 2005, http://www.learningcircuits.org/2005/aug2005/devries.htm

Dietinger, T. (2003). Aspects of E-learning environments. Graz University of Technology. Retrieved May, 2006, from http://www.iicm.edu/thesis/tdieting diss.doc

Keegan, D. (1993). Theoretical principles of distance education. Routledge, New York.

Shareable Content Object Reference Model. (n.d.).Retrieved October, 2006, from: http://searchwebservices.techtarget.com/sDefinition $/ 0$, sid26_gci796793,00.html

Vpis študentov na višje strokovne šole, univerze in samostojne visokošolske zavode, Slovenija, 2006/07 začasni podatki. (Student enrolment in vocational colleges, universities and free-standing higher education Institutions, Slovenia, 2006/07 - provisional data). Retrieved December, 2006, from http://www.stat.si/novica prikazi.aspx?id=597

Martin, K., Quigley, M.A., \& Rogers S. (2005). Implementing a learning management system globally: An innovative change management approach. IBM Systems Journal, 44, 1.

Razpis za vpis v višje strokovno izobraževanje v študijskem letu 2006/2007. (Notice for enrolment in vocational colleges in academic year 2006/2007). Retrieved February, 2006, from

http://www.mss.gov.si/si/okroznice_razpisi_in_javna narocila/javni_razpisi/?tx_t3javnirazpis_pi $1 \% 5$ Bshow single $\% 5 \mathrm{D}=390$

Steyn, D. (2001). Creating a learning organisation, using information technology. Retrieved October, 2006. from http://upetd.up.ac.za/thesis/submitted/etd-10172005-141454/unrestricted/00Front.pdf

\section{Biographies}

Marko Kastelic is a teacher of Information and Computer Science at the Upper Secondary School of Electrical and Computer Engineering Ljubljana (SSER) and associate teacher at the Education Centre of the Slovenian Electric Power Authority (ICES). He is responsible for directing and implementing e-learning initiative within the SSER. Besides teaching, he works as solution implementator in the fields of open source Learning (Content) Management Systems. His last research and projects refer to the evaluation of the learning course development model, the impact of e-learning, and implementation of e-learning policies and procedures.

Tea Lončarič is a teacher of Computer Science and Information at the vocational college Leila. She has been teaching programming languages and databases at the Upper Secondary School of Electrical and Computer Engineering Ljubljana for the past 14 years. Her research interest includes use of IT in adult education with emphasis on web-based teaching and web-based learning issues. Her last projects refer to the research of open source tools for development of e-materials and e-assessments. 